\title{
EMPLOYMENT TRANSITIONS IN 13 EUROPEAN COUNTRIES. \\ LEVELS, DISTRIBUTIONS AND DETERMINING FACTORS OF NET REPLACEMENT RATES
}

\author{
HERWIG IMMERVOLL \\ CATHAL O’DONOGHUE
}

\section{CESIFO WORKING PAPER NO. 1091 \\ CATEGORY 4: LABOUR MARKETS \\ NOVEMBER 2003}

Presented at Venice Summer Institute, Workshop on Tax Policy and Labour MARKET PERFORMANCE, JULy 2003

\footnotetext{
An electronic version of the paper may be downloaded

- from the SSRN website:

- from the CESifo website:

www.SSRN.com

www.CESifo.de
} 


\title{
EMPLOYMENT TRANSITIONS IN 13 EUROPEAN COUNTRIES. LEVELS, DISTRIBUTIONS AND DETERMINING FACTORS OF NET REPLACEMENT RATES
}

\begin{abstract}
This paper utilises a multi-country microsimulation tax-benefit model for Europe, EUROMOD, to simulate the distribution of net replacement rates for 13 European countries. We look at different types of labour market transitions by comparing household incomes in the current state with simulated in-work/out-of-work counterfactuals. In particular we compare how the importance of household composition and different income sources varies across countries and for different replacement rate bands. We also show which individual and household characteristics are associated with observed replacement rate levels.
\end{abstract}

JEL Classification: H31, J65, E60, C81.

Keywords: net replacement rate, unemployment benefits, work incentives European Union, microsimulation.

\author{
Herwig Immervoll \\ Dept of Applied Economics \\ University of Cambridge, \\ Sidgwick Avenue \\ Cambridge, CB3 9DE \\ United Kingdom \\ h.immervoll@econ.cam.ac.uk
}

\author{
Cathal O'Donoghue \\ Department of Economics \\ National University of Ireland \\ University Road \\ Galway \\ Ireland \\ cathal.odonogue@nuigalway.ie
}

\begin{abstract}
This paper was written as part of the EUROMOD project, financed by Targeted Socio-Economic Research programme of the European Commission (CT97-3060) and partially while Cathal O'Donoghue was a SAGE Visiting Fellow at the London School of Economics and an ICER Fellow at the University of Turin. He acknowledges gratefully the hospitality provided. We thank Sonia Bhalotra, Klaas de Vos, Maria Laura Di Tomasso, Marcel Gerard, Magda Mercader, Holly Sutherland, Heikki Viitamäki and Terry Ward for helpful comments on earlier versions of this paper. We also benefited from comments received from seminar participants at a CESifo seminar in Venice, at the LSE (STICERD), and the University of Cambridge. We also thank all past and current members of the EUROMOD consortium for their contributions to the construction of the EUROMOD model. The views expressed in this paper as well as any errors are the authors' responsibility. In particular, EUROMOD is continually being improved and updated. The results presented here represent work in progress. The authors alone are responsible for the interpretation of model results and for any errors in the use of EUROMOD.
\end{abstract}




\section{INTRODUCTION ${ }^{1}$}

It has been argued that the structure of tax-benefit systems in OECD countries has been the cause of labour market problems (for instance OECD, 1997a). In particular, there is a concern that tax-benefit systems create incentives that negatively affect the behaviour of both employees and firms. On the demand side, high tax burdens can increase the cost of labour while on the supply side, high marginal tax rates reduce the reward for additional work efforts at the intensive margin. At the extensive margin, generous out of work benefit payments are seen to lead to reduced efforts to seek gainful employment or remain in work (Snower, 1997). These disincentives have been named as one of the main causes of slack economic growth and unemployment (European Commission, 2000).

Using a new EU-wide microsimulation model, it is possible to compare across countries the combined effects of taxes and benefits on household incomes both in and out of work. While Immervoll (2002) has analysed distributions of marginal and average effective tax burdens faced by employees, the present paper focuses on the role of taxes and benefits on household incomes during transitions into and out of work. In particular, we provide detailed measures of so-called net replacement rates (the ratio of out of work income to in work income).

Net replacement rates (NRRs) provide a useful starting point for identifying to what extent workers are protected from income loss due to unemployment. This is important in order to evaluate whether benefit systems provide households with a sufficient amount of resources during periods of employment transitions. At the same time, NRRs allow us to address the question whether the financial gains to employment may be insufficient and, importantly, why this may be the case. By relating NRRs to information recorded in rich mico-data sets, we can analyse the factors behind observed NRR levels (such as wage and benefit levels or household composition).

To address these questions, a micro-based analysis is essential. However, calculations based on average or "typical" households often provide a useful first step in any comparative analysis. For instance, the OECD provide regular assessments of both gross and net replacement rates across OECD countries for a range of family types (e.g., OECD, 2002). Another useful background to the present analysis is the series of studies (OECD, 1997a, 1997b) highlighting the significance of the so-called unemployment trap.

\footnotetext{
${ }^{1}$ Address for correspondence: Microsimulation Unit, Department of Applied Economics, University of Cambridge, Sidgwick Avenue, Cambridge, CB3 9DE, UK. Email: h.immervoll@econ.cam.ac.uk, cathal.odonoghue@nuigalway.ie. A version of the paper is also available in the EUROMOD Working Paper Series (www.econ.cam.ac.uk/dae/mu/emod.htm).
} 
This paper extends the developmental work carried out for four EU countries in Immervoll and O'Donoghue (forthcoming (a)) that quantified the distribution of NRRs for a selected number of individual and household characteristics and Immervoll and O'Donoghue (forthcoming (b)) that developed a method for decomposing NRRs into the factors that drive them. These papers documented the extent to which younger people, women, households with more than one adult and households with children in general had higher NRRs and highlighted the impact different income sources have on the distribution of NRRs in these countries. In this paper we extend the analysis to 13 countries of the EU.

We first derive NRR averages and distributions for employment transitions into and out of work. The microsimulation model is used to compute the counterfactual income situations (out-of-work benefits for the transition out of work; in-work earnings for the transition into full-time employment). Any knock-on effects on other taxes and benefits received by the person whose status changes as well as other household members (such as lower income taxes in the out-of-work situation) are taken into account. NRRs are derived by comparing the counterfactual with the original situation observed in the micro-data.

In a second step, we take a closer look at what causes observed NRRs. This is done by first looking in detail at all relevant income components and how they might change following employment transitions. In addition, we formulate a simple regression model where NRRs are regressed on a set of individual and household characteristics in order to identify and compare associations between them.

While NRRs are one manifestation of the tax-benefit rules which influence labour supply incentives and while microsimulation models can provide very detailed information on the budget sets used as an input for labour supply models, this paper does not try to determine whether and to what extent these financial incentives determine behaviour. Instead, we report the size and distribution of NRRs along with factors that influence them. It is a matter for labour micro-econometricians to evaluate the quantitative importance of any associated work incentives.

The paper is structured as follows. In section 2 we briefly summarise the most important measurement issues related to quantifying replacement rates. The microsimulation model and data are also described here. Section 3 presents the main characteristics of the 13 tax-benefit systems in terms of the structure of taxes and benefits as well as their distributional impact. NRR simulation results and decompositions are presented in section 4 and discussed in section 5. Section 6 concludes.

\section{Methodology}

Replacement rates are a measure of the degree to which an individuals' (and their households) standard of living while in work is maintained during periods of unemployment. The higher a household's replacement rate, the more protected they are from the impact of losing work income. At the same time, however, high replacement rates may reduce peoples' efforts to secure employment. The labour market opportunities that unemployed people face may be such that accepting jobs offered to them would not result in any or little financial gain. This may be particularly true for low-skilled people. Similarly, those currently employed (particularly on low wages) may not lose much by entering (spells of) unemployment. 
Obviously unemployment benefits play an important role in this. ${ }^{2}$ In addition to unemployment benefits, many other features of the tax-benefit system will determine the difference between incomes in and out of work. A progressive tax system can dampen the income loss by making net incomes less variable than gross incomes. For example, progressive income taxes on earnings combined with a favourable tax treatment of benefits mean that replacement rates before taxes are markedly lower than NRRs, which are measured net of tax and contribution payments (OECD 1997a). Benefits that do not depend on income or the employment status also smooth income differences between in- and out of work. On the other hand, benefits (or tax rebates) that are conditional on employment or a certain minimum number of working hours can serve to increase the difference between in-work and out-ofwork incomes. NRRs capture all these influences by taking into account all relevant tax- and benefit changes following an employment transition.

Immervoll and O'Donoghue (2001b and forthcoming (b)) describe in some detail the analytical choices faced in calculating replacement rates (see also Atkinson and Micklewright, 1991). The two basic dimensions that are relevant in this context are (1) which income components to include in the numerator and the denominator of the replacement rate and for whom; and (2) which direction of labour market transition to compute the replacement rate for.

In measuring the degree of income maintenance, we have two main alternatives regarding the definition of income. If we see out of work benefits as an insurance system then one could be interested in measuring the degree to which in-work incomes are insured. In this case, the numerator would be (net) out of work benefit income and the denominator would be (net) income from work. Only incomes of the one person whose labour market status changes would be taken into account while incomes of any other household members would be disregarded. Or one could be interested in the living standard out of work as opposed to in work. In this case, both numerator and denominator would also include all other incomes including, for example, income from capital and benefits that are independent of work status. Also, given the interest in living standards, a household concept will usually be appropriate so that incomes of all other household members should be included as well.

We adopt the latter type of calculation since we regard the question of relative living standards the more interesting one. The definition of income considered is disposable income, defined as market incomes (employment plus other market incomes) plus benefits minus social insurance contributions minus income taxes. Since for twelve of the thirteen countries we are looking at, our data contain annual incomes (the exceptions are the UK and Ireland where data are weekly), we have chosen the year as the relevant period.

The existence of other household members, will influence NRR results in two ways. First, the larger the number of other household member with incomes, the smaller will be the income difference if one person changes between work and unemployment. In comparing results across countries one will therefore have to bear in mind differences such as the number of

\footnotetext{
${ }^{2}$ In this context, the generosity of unemployment benefit systems can be relevant even if benefits are not paid when unemployment is judged to be 'voluntary': Employers may use the unemployment insurance to smooth over demand cycles by laying off people when demand is weak and re-employing them when business is stronger. There has been some evidence that such temporary layoffs are important phenomena especially in the US but also in some European countries. See Jensen and Westergard-Nielsen (1989).
} 
two-earner couples or adult children living with their parents. ${ }^{3}$ A second influence will be due to the tax-benefit system: the employment status and income of one person may affect taxes and benefits of other household members and, thus, total household incomes in- and out of work.

In order to compute the counterfactual income situation for a household, we have to decide for which of the household members we want to simulate the employment transition. The individuals we consider for the transition are those of working age (18-59). We exclude civil servants since they frequently do not face the same unemployment risks and would thus complicate comparisons across countries. People in education are also excluded. Of course we need to also decide on the type of transition which, in turn, will depend on the person's original employment status observed in the micro-data. For people who are observed to be out of work, we will simulate a transition into work as the counterfactual income situation and vice versa. Many studies of replacement rates have focused exclusively on the unemployed and have computed their current income as a fraction of the prospective income they would earn if entering employment (e.g., Salomäki and Munzi, 1999 and O'Donoghue and Utili, 2000). In the present analysis we consider the following three labour market states: (A) employed or self-employed; (B) unemployed; (C) out of work other than unemployed. The transitions we simulate are: (1) from A to $\mathrm{B}$ (we will call this replacement rate $R R_{a b}$ ), (2) from $\mathrm{B}$ to $\mathrm{A}\left(R R_{b a}\right)$ and $(3)$ from $\mathrm{C}$ to $\mathrm{A}\left(R R_{c a}\right)$. The sample size for each transition will therefore depend on the number of working age people in labour market states A, B and C. Table A2 in the annex shows the resulting sample sizes for each transition across countries. ${ }^{4}$

$R R_{a b}$ is the "in work" NRR for somebody currently in employment or self-employment (perhaps part-time) and moving into full-time unemployment. $R R_{b a}$ and $R R_{c a}$ represent what we call "out of work" NRRs. $R R_{b a}$ is the replacement rate for a transition into full-time employment applying to those who are currently receiving unemployment benefits or who classify themselves as being 'unemployed' and seeking work in our data. $R R_{c a}$ denotes the level of current (net) income relative to the prospective (net) full-time employment income of someone currently out of work but not 'unemployed'. It is, in other words, the out of work replacement rate faced by working age individuals who receive neither income from work nor unemployment benefits (e.g., 'inactive' people; those engaged in unpaid care or domestic work; recipients of pensions, disability benefits, social minimum benefits, etc). It is an advantage that we can investigate the 'inactive' group separately, however one must be very cautious in drawing conclusions for this group as a whole as it is very heterogeneous. As a result, our analysis will mainly focus on $R R_{a b}$ and $R R_{b a}$.

The transition is assumed to take place at the start of the fiscal year (with the employment status remaining unchanged thereafter). As mentioned above, we compare income situations in- and out of work over a full year. As a result, we do not currently take into account any changes in benefit levels that may occur after a period longer than 12 months following the

\footnotetext{
${ }^{3}$ In computing one measure for the entire household, we implicitly assume equal sharing of resources within the household. Where this is not appropriate (e.g., in cases where two family units share one physical household) our replacement rate results will tend to underestimate the change in living standards due to employment transitions.

${ }^{4}$ Note that, in cases where micro-data record annual income information, the sample sizes of the three groups will generally not sum up to the total number of working age persons because, frequently, people have more than one labour market status during the year. In these cases, we simulate all relevant transitions for this person. See Immervoll and O’Donoghue (2001b) for details.
} 
transition. ${ }^{5}$ In particular, $R R_{a b}$ measures the initial unemployment benefit that people currently in work would receive if they became unemployed relative to current in-work income. For all transitions, all income components other than the simulated taxes and benefits remain unaffected for members of households whose labour market status does not change. In addition, we assume that all other household characteristics remain unchanged so that any behavioural adaptations (such as the use of childcare services or altering housing decisions) to the new employment situation are ignored.

\section{EUROMOD}

Simulations are run for 13 EU countries (Finland and Sweden are excluded at present). The micro data sets underlying the simulations are shown in table A1. ${ }^{6}$ The model used to simulate replacement rates is EUROMOD, an integrated European tax-benefit model. EUROMOD provides us with a Europe-wide perspective on social and fiscal policies that are implemented at European or national level. It is also designed to examine, within a consistent comparative framework, the impact of national policies on national populations or the differential impact of co-ordinated European policy on individual Member States. Within the context of the present paper, the most relevant feature of EUROMOD is that it can provide conceptually consistent and, thus, comparable output for different countries. See Immervoll and O'Donoghue (2001a) and Sutherland (2001) for details about the model and underlying data.

The simulations are based on the systems of tax and benefit rules current in June 1998 and all monetary variables in the micro-data are updated from their original value to 1998 using the most appropriate uprating index available for each type of variable. ${ }^{7}$ In computing total disposable incomes, income components that do not lend themselves to simulation ar etaken directly from the data (e.g. pensions). The standard tax-benefit instruments simulated in EUROMOD and relevant for this exercise are income taxes, social insurance contributions, child benefits and other family benefits, and income- or means-tested benefits. ${ }^{8}$ Detailed

\footnotetext{
${ }^{5}$ Relevant benefit changes during the 12 months period (such as waiting periods or the expiration of Job Seekers Allowance in the UK after, at most, 6 months) are fully taken into account.

${ }^{6}$ EUROMOD relies on micro-data from 11 different sources for fifteen countries. The data sources used for the current study are the European Community Household Panel (ECHP) made available by Eurostat; the Austrian version of the ECHP made available by the Interdisciplinary Centre for Comparative Research in the Social Sciences; the Living in Ireland Survey made available by the Economic and Social Research Institute; the Panel Survey on Belgian Households (PSBH) made available by the University of Liège and the University of Antwerp; the Income Distribution Survey made available by Statistics Finland; the Enquête sur les Budgets Familiaux (EBF) made available by INSEE; the public use version of the German Socio Economic Panel Study (GSOEP) made available by the German Institute for Economic Research (DIW), Berlin; the Survey of Household Income and Wealth (SHIW95) made available by the Bank of Italy; the Socio-Economic Panel for Luxembourg (PSELL-2) made available by CEPS/INSTEAD; the Socio-Economic Panel Survey (SEP) made available by Statistics Netherlands through the mediation of the Netherlands Organisation for Scientific Research - Scientific Statistical Agency; and the Family Expenditure Survey (FES), made available by the UK Office for National Statistics (ONS) through the Data Archive. Material from the FES is Crown Copyright and is used by permission. Neither the ONS nor the Data Archive bear any responsibility for the analysis or interpretation of the data reported here. An equivalent disclaimer applies for all other data sources and their respective providers cited in this acknowledgement.

${ }^{7}$ A new "wave" of EUROMOD data is currently being added to the model and is often "closer" to 1998 than the first data available for the model.

${ }^{8}$ In the current exercise, we assume full benefit take-up and no tax evasion.
} 
descriptions of the tax-benefit rules built into the model are provided in the "EUROMOD country reports" (available through www.econ.cam.ac.uk/dae/mu/emod.htm).

For the present study and as explained above, we also simulate unemployment benefits (for the transition out of work). ${ }^{9}$ Unemployment benefits in a number of the countries depend upon previous income. When simulating the transition from work to unemployment, we utilise existing in-work income in the data as previous income. Also some individuals are ineligible for unemployment benefits because they were self-employed. Our simulations take this into account. However, having no full information on the reasons for unemployment or the time in work prior to unemployment, we assume that unemployment is involuntary and that people satisfy any contribution requirements (having started work no earlier than at age 18). In this sense, the computed $R R_{a b}$ can be seen as an upper boundary estimate in cases where unemployment benefits depend on contribution records. On the other hand, we abstract from any early retirement provisions which, in comparison with the unemployment benefit system, may provide more generous out-of-work benefits in some countries.

For transitions into work $\left(R R_{b a}, R R_{c a}\right)$ we know people's out-of work benefits and instead need to simulate in-work earnings (along with all related taxes and benefits) as the counterfactual situation. The goal here is not a very precise prediction of potential earnings for each individual but to capture the essential features of the distribution of potential entry wages reflecting the labour market opportunities of out-of-work people. We use a standard ( $\log$ ) earnings model to estimate in-work income for those currently out of work, utilising the Heckman (1979) procedure to account for sample selection bias. ${ }^{10}$ This method "adjusts" coefficients of explanatory variables to account for the possible selection bias associated with the fact that we only observe earnings for those who work in data. We estimate separate models for men and women. The estimated coefficients and standard deviations are reported in table A3. The results of estimating the earnings of the unemployed from these equations (for 1998) generally show that they have a lower earnings potential on average than those in work. At the same time, there tends to be a smaller proportion of the unemployed with high earnings potential than in the case of those who are actually in employment and a larger proportion with relatively low earnings potential. ${ }^{11}$

\section{TAX-BENEFIT SYSTEMS}

The thirteen countries we consider represent very different welfare state regimes in Europe. As a background to the replacement rate results it is therefore useful to take a brief look at some of the main features of countries' tax-benefit systems. Table 1 reports the importance of different instrument groups as a percentage of household disposable income and the amount of redistribution in the tax-benefit system as measured by the change in the Gini coefficient. In what follows we discuss these indicators in relation to an often-used typology of welfare states:

\footnotetext{
${ }^{9}$ Immervoll and O'Donoghue (2001) describe in more detail the assumptions underlying the simulation of unemployment benefits

${ }^{10}$ We thus assume that the selection bias is the same for all 'out of work' groups whereas it may be more conceptually appropriate to treat different 'out of work' groups such as involuntary unemployed differently from other out-of-work groups such as home-workers. However, for cross-country studies like the present one, the use of a single participation equation seems preferable to us on transparency grounds.

${ }^{11}$ Further details on the earnings equation as well as a comparison of predicted earnings and actual earnings is provided in Alphametrics and Microsimulation Unit (2002).
} 
- “Universal": Denmark, (Netherlands);

- “Conservative": Austria, Belgium, France, Germany, Luxembourg, (Netherlands);

- "Southern": Greece, Italy, Portugal, Spain;

- "Liberal": Ireland and the UK.

\section{Relative Size of Benefit Expenditures and Tax Revenues}

We see from table 1 that countries with Universal or Conservative welfare states tend to have benefits and benefits exceeding 30\% of total disposable income with Liberal and Southern Welfare states with benefits expenditure less than $30 \%$ of disposable income. Italy is an exception due to relatively high public pensions and social assistance (mainly the social minimum components of public pensions). The Netherlands, on the other hand, has lower total benefits than other countries in the Universal or Conservative group. The importance of private provision for retirement pensions is a decisive factor here. The reliance on private pensions is particularly pronounced for Ireland and the UK resulting in low total benefit expenditures.

Except in the case of Ireland, where means-tested social assistance benefits dominate, expenditures on contributory pensions (the main part of the "other benefit" category) are highest. While in a few countries such as Austria early retirement pensions are frequently substitutes for unemployment benefits, pensions will generally only have a limited impact upon working age replacement rates and will have no impact at all on NRRs computed for transitions out of work $\left(R R_{a b}\right)$.

Denmark and Belgium have the largest expenditure on social insurance unemployment benefits, followed by Germany, France and the Netherlands. The remaining countries have low unemployment benefit expenditure for a variety of reasons such as low unemployment, low benefit payments, low coverage or duration. Although unemployment insurance benefits in most countries are earnings related benefits, Ireland and the UK have flat rate benefits. Duration of receipt is also an issue. For example in the UK, unemployment benefits are payable only for at most 6 months. Durations are also short in the Southern countries. In many countries coverage of these benefits is limited to employees, with the self-employed excluded. This is also true for the Southern countries and Irleand where a higher proportion of selfemployed tends to reduce unemployment benefit coverage.

Turning to the minimum income benefits heading, we the largest shares in Liberal countries. Ireland stands out in particular. Means-testing there is important because of a combination of factors such as the lack of earnings related benefits, coverage gaps and low durations of insurance benefits. After the short entitlement to unemployment benefits in the UK, unemployed individuals living in low-income household become eligible to Income Support. Income Support in the UK can also top up family incomes to the social minimum while in receipt of (flat amount) unemployment benefits. In most other countries, individuals exhausting their entitlement to social insurance unemployment benefits also become eligible for means tested unemployment (Austria, Germany and the Netherlands) or social assistance benefits. The maximum durations of insurance benefit receipt as well as the profile of benefit amounts over time are however quite different across countries (see OECD, 2002). In Spain, 
certain older workers and those with children may be eligible for unemployment assistance, but entitlement is generally quite limited. In Italy there is no entitlement once unemployment benefits are exhausted. Much of the social assistance payments in the Southern countries as well as in some other countries are also targeted at elderly people and so may be seen as a substitute for pensions rather than unemployment benefits. In some countries, another important determinant of income when out of work (or in low-paid jobs) are means tested housing benefits, especially in the UK, Denmark and France. As an expenditure group, they are not significant in other countries.

In 7 countries out of 13, family benefits are the second most important expenditure group and are highest Luxembourg, Belgium, Denmark and Austria. Because they are generally not income related, they serve to smooth income transitions into and out of work. ${ }^{12}$

On the revenue side, we classify three types of instruments: income taxes and social insurance contributions paid by employees (or benefit recipients) and employers. As a percentage of disposable incomes, in Belgian total taxes are clearly highest in Belgium and Denmark with Belgium (but not Denmark) also having the largest relative benefit expenditures. "Conservative" countries are all in the 50-60\% range, the Southern countries mainly in the 40$50 \%$ range and Greece, Spain and the UK around or below 30\%. At around one fourth of disposable income the smalles tax share is found for Ireland.

The structure of revenue raising instruments varies a great deal across countries. There is also little consistency within similar "welfare systems" groups. Income taxes in Ireland and the UK are large but social insurance contributions are very low. The highest income taxes are paid by Danes. Income taxation is also the most important instrument in Germany, Italy, Luxembourg and Spain. Employer social insurance contributions are the most important (direct tax) revenue-raising instrument in four countries. As the income base for income taxes is wider, there may, for a given revenue raised, be less of an upwards pressure upon replacement rates than for social contributions. On the other hand, the more progressive the a tax, the larger will be its (upwards) influence on replacement rates.

Different designs of income taxation are in use across countries. One aspect that matters in particular when analysing replacement rates is whether incomes are assessed separately for each individual or jointly. While most countries operate individual based tax systems, a number of countries tax couple (or family) income. (see O'Donoghue and Sutherland, 1999). These include, France, Germany, Ireland, Luxembourg, Portugal and Spain. Yet, even in countries where tax schedules are formally "individual" there can be sizable "joint" elements (e.g., due to tax free allowances that are transferable between spouses) so that the employment status and earnings of one spouse can have important implications for the tax liability of the other.

\section{Redistribution}

The degree of redistribution within a tax-benefit system depends not only on the size of the an instrument, but also on the degree of targeting or progressivity. In the second part of the table, we report the Gini measure of inequality for three different income definitions, gross market

\footnotetext{
${ }^{12}$ In a number of countries, family benefits are, to varying degrees, income related (Austria, France, Germany, Italy and Spain).
} 
income, including all market source of income, before employer contributions are deducted, gross total income (gross market income plus benefits), and disposable income (total income minus taxes). The difference between the Gini for gross market and gross total incomes corresponds to the redistribution (including any reranking) due to the benefit system in each country and the difference between gross and disposable incomes corresponds to the redistribution due to the tax and social insurance contribution systems.

For pre tax-benefit (gross market) income we typically find Gini coefficients of between 50 and $60 \%$. Inequality of gross market incomes is lowest in Austria and the Netherlands. Although not exclusively so, the "Conservative" and Universal welfare states tend to have lower inequality of market incomes due to higher education levels, greater union power and/or other policies that promote equality in society. Ireland and the Southern Welfare states have amongst the highest inequality in market income. Belgium, despite having one of the lowest inequality levels in terms of disposable income has the highest inequality in market income. Clearly, the Belgian tax-benefit system is very redistributive.

For all countries, we see that benefit systems reduce inequality by more than taxes. Taxbenefit systems in Southern (Conservative) welfare states tend to be least (most) redistributive with Liberal welfare regimes coming between. Outside this general pattern, we find Austria and the Netherlands with relatively low redistribution and Spain with rather large changes in Gini coefficients. In the first two countries, inequality of market incomes is already low and so there is less a role for benefits. In Spain, the high pension related expenditures have a strong redistributive effect.

\section{RESUlts}

\section{Distribution of Net Replacement Rates}

Table 2 presents, for the 13 countries, average NRRs as well as the proportion of people with replacement rates of less than $40 \%, 40-80 \%$ and $80 \%$ or higher for each of the three types of transition. The top section shows the distribution of replacement rates for those currently in work $\left(R R_{a b}\right)$. The countries with the highest replacement rates (of over $80 \%$ on average) are primarily either those with Conservative welfare states (Austria, France and the Benelux countries) or Universal welfare states (Denmark). With an average of less than $70 \%$ and a minimum of $57 \%$ the lowest in-work NNRs are found in Southern welfare states and the UK. Germany, Ireland and Spain come in-between with average replacement rates in the $70-80 \%$ range.

Turning to the second part of table 2 and to those who are currently unemployed $\left(R R_{b a}\right)$, we find a different distribution of replacement rates. There is less variability across countries than for in-work NRRs $\left(R R_{a b}\right)$. In particular we notice that Portugal, and to a lesser extent Greece and Italy, now has substantially higher replacement rates. The opposite is true for Belgium and, particularly, the Netherlands.

The third type of replacement rates we examine concerns those who are currently "inactive" $\left(R R_{c a}\right.$, bottom part of table 2). Again, we compare net household incomes in the current (out of work) situation with net household incomes that would result if the inactive individual were to move into work. Italy moves from having the lowest average replacement rate to having one of the highest average replacement rates. Replacement rates are also higher for 
Austria where relatively large numbers of people in early retired and generous disability benefits play a role. Average replacement rates are also higher for Greece but much lower than for the in work group for the Benelux countries, Denmark, France and Germany.

\section{The role of taxes, benefits and other household incomes}

To enable us to interpret these results and related them to relevant tax-benefit characteristics, it is useful to break down the various influences. To do this, we now try to explain the difference in the distribution of NRRs rates with reference to the income sources that contribute to them. We disaggregate total out of work income (i.e., the numerator of the NRR) utilising the decomposition elaborated in Immervoll and O'Donoghue (forthcoming (b)):

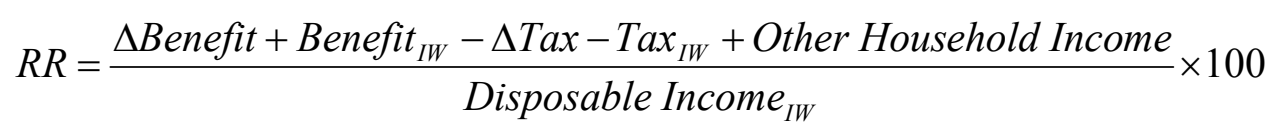

where $\Delta$ Benefit is the change in benefits when moving out of work, Benefit ${ }_{I W}$ is the benefits received by the household when the individual is in work (this includes, but is not limited to, employment conditional or "in-work" benefits), $\Delta T a x$ is the change in taxes and contributions when moving from out of work, $\operatorname{Tax}_{I W}$ is the sum of taxes and contributions paid by the household when the individual is in work and Disposable Income ${ }_{I W}$ is household disposable income when the individual is in work. Other Household Income is the sum of all other household incomes (which is the same in the in work and out of work situations).

In tables 3 (a-c) we report respectively the decomposition of NRRs by income source for the in-work sample $\left(R R_{a b}\right)$, for the unemployed sample $\left(R R_{b a}\right)$ and the "inactive" sample $\left(R R_{c a}\right)$. For convenience, each component is written as a percentage of the average replacement rate for the group.

\section{Characteristics of Individuals with High Replacement Rates}

As a final analytical step we now consider the types of characteristics that influence the distribution of replacement rates considering the in work NRR $\left(R R_{a b}\right)^{13}$ and the unemployed samples $\left(R R_{b a}\right)$ only. Because of the number of countries and dimensions involved, we use a regression model, regressing individual replacement rates on characteristics in an attempt to describe how replacement rates vary across different types of individuals and households. The "explanatory" variables and estimated coefficients are reported in table 4. A regression along these lines can be somewhat heroic (as indicated by very low R2 for some countries, particularly Denmark and the Netherlands). But as a descriptive tool it allows us to conveniently compare across countries. In addition, the estimated coefficients capture any interactions between different characteristics which would not be obvious from simple cross tabulations.

\section{DISCUSSION}

Which characteristics are associated with the various replacement rate levels? We see from table 4 that women's replacement rates are higher than men's in all countries. There are a

\footnotetext{
${ }^{13}$ For comparability purposes we include only those who are in full-time work.
} 
number of reasons for these differentials. Firstly, it is important to note that they are not due to more generous benefit regimes for women. Rather, women are likely to have lower earnings, both in terms of their hourly wage rates and because of shorter working hours, increasing replacement rates. In addition, and as we shall see below, household composition plays an important role, with working women having a high probability of living with partners who have higher earnings. If the husband's earnings are the main source of household income then income will, in relative terms, not fall by very much if the woman loses her job. The (household based) replacement rate she is facing will therefore be relatively high - with possible implications for work incentives.

Young people tend to have higher replacement rates for similar reasons. Firstly, younger people will have lower (actual and potential) in-work earnings than older people and thus have higher replacement rates as unemployment benefits typically provide minimum payments ("floors") that younger people are more likely to benefit from. Secondly, they are more likely to live at home with other earners. The importance of household structure is also confirmed by the positive coefficients for household size (which increases the likelihood of other earnings in the household) and negative coefficients for the number of children (which do not provide additional earnings).

The "unemployment rate" variable represents the out of work rate (by gender five year age band). Although in general it has a positive sign, it may be capturing the fact that younger people and women have both higher replacement rates and out of work rates.

\section{Comparing results for the different transitions}

In most countries, fewer unemployed have high replacement rates $(\geq 80 \%)$. There are a number of reasons for this. Firstly in-work replacement rates $\left(R R_{a b}\right)$ measure the replacement rate in the first year of unemployment assuming that people are in fact entitled to unemployment insurance benefits. As the duration of entitlement to unemployment benefits (UB) is normally limited, those who are currently out of work and have been unemployed for longer may cease to be eligible for these benefits. They may then become eligible for lower valued unemployment- or social assistance benefits or nothing as in the case of many unemployed in Southern European countries. In Denmark, where membership in the unemployment insurance scheme is voluntary, those who are observed to be unemployed in the data and are not members of the insurance scheme will not be receiving any unemployment benefits at all (in cases where family income is "low", they would receive social assistance instead). Secondly, UB may fall in value over time as in the case of France. Consequently, even for those in the $R R_{b a}$ sample who are still in receipt of UB, benefit levels may be lower than those received immediately after becoming unemployed (as in the calculation of $R R_{a b}$ ). In the UK and Ireland, benefits become means tested after a period of time and may thus also fall in value. In short, because the duration of unemployment will often be higher for the unemployed sample $\left(R R_{b a}\right)$ than those who are "made" unemployed in our simulations $\left(R R_{a b}\right)$, institutional factors such as duration dependent eligibility and benefit amounts will result in lower replacement rates for the sample of unemployed compared with the sample of working individuals.

On the other hand, the earnings we predict for those moving into work $\left(R R_{b a}\right)$ will be an important factor. Potential earnings of the unemployed going into work will often be lower than earnings of those currently in work. The unemployed will typically have lower education 
levels and/or frequently be younger on average than the population in work. These factors influencing potential earnings will be picked up by our earnings model. Compared to observed earnings, predicted entry wages for the currently unemployed will on average be lower. This will result in a lower denominator and thus higher NRRs.

The two effects therefore run in opposite directions, with the "earnings" effect being relatively stronger in Greece, Italy and Portugal and the "institutional factors" dominating in most other countries where welfare provision is generally better (both in terms of coverage and benefit amounts) and so has more of an impact. For the "inactive" group $\left(R R_{c a}\right)$, results depend strongly on the composition of this groups which is very heterogeneous across countries. It will include early retirement pensioners (who may receive relatively generous benefits and will thus have high NRRs such as in Austria and Italy) as well as home-workers or discouraged workers who withdrew from the labour force and do not receive any benefit (and whose NRRs can therefore be quite low as in Belgium or Germany). Invalidity benefits will play a similar role as early retirement pensions and may combine with the "earnings" effect and with family support to produce larger numbers of individuals facing high NRRs than are found for the other types of transition (Greece, Italy).

\section{Low Replacement Rates}

When considering issues related to work disincentives, one is often particularly interested in high replacement rates. However, we notice at least $10 \%$ of the in-work population $\left(R R_{a b}\right)$ with replacement rates of less than $40 \%$ for the Southern and Liberal welfare state countries. Indeed, more than $20 \%$ of Greek and Italian workers fall into this group. There is a similar if less extreme picture for $R R_{b a}$ (those who are currently unemployed) and $R R_{c a}$ (those who are currently "inactive") groups.

Considering firstly those with replacement rates below $40 \%$ in table 3 , we notice that the contribution of marginal benefits (the extra benefit the household receives when the individual moves out of work) to NRRs is very low compared to other factors. In particular, the lower taxes paid when out of work as opposed to in work are much more important. They almost entirely offset in-work taxes showing that these people live in very low income household where, if they lose their job, almost no taxes are paid at all. In some of the countries with large numbers of low $R R_{a b}$, marginal benefits are particulary low which points to the lack of in-work income insurance as a main cause of insuffient resources when out of work.

Benefits in work may be universal benefits (such as family benefits), means-tested benefits in households ("working poor") or unemployment benefits paid to other individuals in the household who are out of work. In countries operating in-work benefits (in 1998 Ireland and the UK) they will also include benefits that are conditional upon employment and are thus only paid when in work. The Benefits in work component is typically the highest in the Southern countries. One of the reasons for this is that household sizes in Southern countries are typically larger than other countries containing elderly relatives in receipt of pensions for example, many with a single main breadwinner. If this breadwinner loses his or her job, then low other incomes and benefits together with low replacement benefits results in low RRs. This is confirmed by relatively high poverty rates and gaps in these countries, when the main breadwinner in a family loses their job. 
The remaining component of the replacement rate is the influence of other household income, either non-employment income of the individual who makes the transition or any type of market income of other individuals living in the same household. In Greece, Italy and Portugal, other incomes are on average the most important compared with other countries. For some groups in other countries, these incomes are important, but typically there are very few people in non-southern European countries with NRRs this low.

\section{Medium and High Replacement Rates}

We now consider together the groups of individuals with replacement rates of $40-80 \%$ and $80+\%$. Comparing with the low NRR group, we see that as NRRs are rising, the share of marginal benefits is falling. However, this does not mean that benefits are less relevant for higher replacement rates. Indeed, for the $40-80 \%$ NRR group we see that, because the contribution of other components is falling as well, that marginal benefits are very important. Yet, for the $>80 \%$ group we clearly see the importance of marginal benefits drop far below that of other household incomes. Even though other household income was the most important for the low replacement rate group, this income component increases in importance as one ascends the RR distribution, resulting in the conclusion that the existence of other income, mainly the income of spouses and parents act as the most important income source in maintaining living standards when out of work.

\section{Concluding Remarks}

In this paper, we have used the EUROMOD tax-benefit model to derive distributions of replacement rates in 13 EU countries and to decompose the effect of different income sources on the distribution of net replacement rates.

We noticed that patterns of incomes of different types of individuals (currently in work, unemployed or inactive) with high replacement rates were very different. This highlights the importance of using micro-based simulation methods when trying to measure replacement rates or when quantifying the elasticity of labour supply resulting from these replacement rates. Averages will not suffice particularly when one is concerned, as is often the case, with the more "unusual" cases at the fringes of the labour market.

Using the tax-benefit model, we are able to isolate the influence of social and fiscal policy factors and other incomes that determine the level of out of work income versus income when in work. In general the tax-benefit system is not in fact the main "preserver" of household income. The presence of income from parents, spouses or other individuals in the household is likely to have a stronger impact on income maintenance and thus on the existence of high replacement rates than tax-benefit instruments. Because of this, replacement rates may not necessarily be the best indicator of the isolated impact of taxes and benefits on income replacement. They are essential, however, for understanding the context in which employment transitions take place. While it is desirable to break down replacement rates to separately show the factors that drive them, it would be misleading to focus on any one of those factors in isolation. For instance, marginal effective tax rates computed for transitions into work ${ }^{14}$ can show very clearly the effective gain from employment. But since they do not relate this to the

\footnotetext{
${ }^{14}$ This measure has also been called "Average Effective Tax Rate" (OECD, 2002), "Participation Tax Rate" (Immervoll et al, 2003) or "Tax-Benefit to Earnings Ratio" (Immervoll and O’Donoghue, 2001b).
} 
original level of household resources, it is not clear what financial difference a transition into work would make to the household as a whole.

Future work in this area could attempt to address some of the asymmetries that exist between the simulation of the various transitions. For transitions out of work, for instance, it would be desirable not to restrict the reference time period to one year. Instead one could utilise empirical distributions of unemployment durations (as measured in Labour Force Surveys) and assume that expected unemployment durations are distributed the same way. This would permit a more realistic weighting of the various benefit levels available during a period of unemployment and may thus better capture the true financial trade-off people are facing when making labour supply choices.

\section{REFERENCES}

Alphametrics and Microsimulation Unit, 2002. "Analytical and statistical tools for monitoring EU tax-benefits systems. Report of a study funded by DG Employment and Social Affairs, European Commission”, Royston: Alphametrics Limited.

Atkinson, A.B. and J. Micklewright, 1991. "Unemployment compensation and labour market transitions: A critical review", Journal of Economic Literature, v29, pp. 1679-727.

European Commission, 2000. Employment in Europe 2000. Brussels.

Heckman, J., 1979. "Sample selection bias as a specification error", Econometrica, v47, pp. $153-161$

Immervoll, H., H.J. Kleven, C.T. Kreiner and E. Saez, 2003. "Welfare Reform in European Countries. A Microsimulation Analysis.”, mimeo.

Immervoll, H., 2002. "The Distribution of Average and Marginal Effective Tax Rates in European Union Member States", EUROMOD Working Paper no. 2/02, available through www.econ.cam.ac.uk/dae/mu/emod.htm.

Immervoll, H. and C. O’Donoghue, 2001a. "Towards a Multi-Purpose Framework for TaxBenefit Microsimulation: A Discussion by Reference to EUROMOD, a European Tax-Benefit Model", EUROMOD Working Paper no. 2/01, available through www.econ.cam.ac.uk/dae/mu/emod.htm.

— and -, (2001b). " Welfare Benefits and Work Incentives, An Analysis of the Distribution of Net Replacement Rates in Europe using EUROMOD, a Multi-Country Microsimulation Model ", EUROMOD Working Paper no. 4/01, available through www.econ.cam.ac.uk/dae/mu/emod.htm.

— and —, forthcoming (a). "What Difference does a Job Make? The Income Consequences of Joblessness in Europe", in Gallie D. (ed.) Resisting Marginalisation: Unemployment Experience and Social Policy in Western Europe. Oxford: Oxford University Press

— and —, forthcoming (b). "Decomposing Replacement Rates", IZA Discussion Paper. 
—, - and H. Sutherland, 1999. "An Introduction to EUROMOD", EUROMOD Working Paper no. 0/99, available through www.econ.cam.ac.uk/dae/mu/emod.htm.

Jensen, P. and N. Westergard-Nielsen, 1989. "Temporary Layoffs", Labour Economics Group Working Paper, University of Aarhus and Aarhus School of Business, 89-2.

O'Donoghue, C. and H. Sutherland, 1999. "For richer, for poorer?: The treatment of marriage and the family in European income tax systems", Cambridge Journal of Economics, Vol. 23, No. 5.

O'Donoghue, C. and F. Utili, 2000. "Micro-Level Impacts of Low Wage Policies in Europe", Salverda W., B. Nolan and C. Lucifora (eds.), Policy Measures for Low-Wage Employment in Europe. London: Macmillan.

OECD, 2002. "Benefits and Wages. 2002 Edition”, Paris: OECD.

-, 1997a. Making work pay. Taxation, benefits, employment and unemployment. Paris: OECD.

OECD, 1997b. "Making Work Pay" in Employment Outlook, Paris: OECD.

OECD, 1994. The OECD Jobs Study. Paris: OECD.

Salomäki, A. and T. Munzi, 1999. "Net replacement rates of the unemployed: Comparisons of various approaches", EC DG ECFIN Economic Papers, No 133.

Snower, D.J., 1997. "Evaluating unemployment policies: What do the underlying theories tell us?", in D.J. Snower and G. De La Dehesa (eds.), Unemployment policy: Government options for the labour market, Cambridge: Cambridge University Press, pp. 15-53.

Sutherland, H., 2001. "Final Report. EUROMOD: An integrated European benefit-tax model", EUROMOD Working Paper EM9/01, available through http://www.econ.cam.ac.uk/dae/mu/emod.htm. 


\section{TABLES AND FIGURES}

Table 1. Characteristics of Tax-Benefit Systems: 1998

\begin{tabular}{|c|c|c|c|c|c|c|c|c|c|c|c|c|c|}
\hline Country & $\mathbf{A T}$ & BE & DK & FR & GE & GR & IR & IT & $\mathbf{L U}$ & NL & PT & SP & UK \\
\hline \multicolumn{14}{|l|}{ As a \% of Disposable Income } \\
\hline \multicolumn{14}{|l|}{ Benefits } \\
\hline Unemployment Benefits (1) & 1.2 & 4.1 & 7.9 & 2.3 & 2.7 & 0.2 & 1.2 & 0.4 & 0.3 & 2.5 & 1.5 & 1.5 & 0.2 \\
\hline Means Tested Minimum Income Benefits (2) & 1.5 & 2.4 & 1.0 & 1.1 & 2.3 & 1.8 & 11.4 & 4.0 & 0.6 & 2.2 & 0.7 & 3.1 & 5.5 \\
\hline Means Tested Housing Benefits (3) & 0.2 & 0.0 & 1.6 & 1.5 & 0.9 & 0.1 & 0.1 & 0.0 & 0.1 & 0.7 & 0.0 & 0.1 & 2.8 \\
\hline Family Benefits (4) & 3.2 & 4.5 & 3.4 & 2.7 & 2.9 & 0.7 & 2.4 & 1.3 & 4.7 & 1.8 & 1.6 & 0.6 & 1.9 \\
\hline Other Benefits incl. Pensions (5) & 31.0 & 28.0 & 19.3 & 25.5 & 23.1 & 19.6 & 6.3 & 25.0 & 26.0 & 18.1 & 19.2 & 22.3 & 11.0 \\
\hline Total Benefits (6) & 37.2 & 38.9 & 33.2 & 33.1 & 31.9 & 22.4 & 21.4 & 30.7 & 31.7 & 25.3 & 23.0 & 27.6 & 21.4 \\
\hline \multicolumn{14}{|l|}{ Taxes } \\
\hline Employer SICs (7) & 20.7 & 35.7 & 3.2 & 28.2 & 17.2 & 6.3 & 3.0 & 18.0 & 10.3 & 15.3 & 19.6 & 13.1 & 6.3 \\
\hline Income Tax (8) & 17.9 & 25.8 & 51.5 & 11.0 & 20.6 & 12.2 & 17.6 & 23.2 & 17.5 & 15.8 & 15.3 & 15.4 & 20.0 \\
\hline Employee SICs (9) & 16.7 & 11.0 & 13.6 & 19.7 & 17.2 & 9.9 & 3.8 & 8.3 & 10.2 & 24.3 & 10.6 & 5.2 & 5.5 \\
\hline Total Taxes (10) & 55.3 & 72.5 & 68.3 & 58.9 & 55.1 & 28.4 & 24.4 & 49.5 & 38.0 & 55.4 & 45.4 & 33.7 & 31.9 \\
\hline \multicolumn{14}{|l|}{ Redistribution (Gini) } \\
\hline Gross Market Income [Market I & 49.4 & 59.5 & 52.9 & 54.5 & 53.7 & 55.6 & 57.4 & 54.2 & 53.2 & 45.9 & 58.2 & 57.7 & 53.9 \\
\hline Gross Income [Gross Market Income plus (6)] & 32.8 & 33.0 & 33.5 & 32.9 & 33.9 & 40.2 & 39.2 & 37.9 & 33.4 & 31.1 & 43.0 & 37.7 & 36.3 \\
\hline Disposable Income [Gross Income less (10)] & 26.6 & 25.7 & 25.7 & 28.3 & 26.3 & 36.7 & 33.1 & 33.9 & 26.5 & 26.4 & 38.2 & 33.1 & 31.8 \\
\hline
\end{tabular}

Source: EUROMOD. Benefit and tax totals are shown in relation to total cash household disposable income before housing costs and other forms of "committed expenditures". Gini coefficients relate to per-capita incomes and counting each individual; any negative income values enter as zero values. The equivalence scale used for deriving per-capita values is of the "modified OECD" type (with weights 1 for the first adult, 0.5 for further adults and 0.3 for children aged under 14). 
Table 2. Distribution of Net Replacement Rates: 1998

\begin{tabular}{|c|c|c|c|c|c|c|c|c|c|c|c|c|c|}
\hline & At & Be & Dk & Fr & Ge & Gr & Ir & It & $\mathbf{L u}$ & $\mathbf{N I}$ & $\mathbf{P t}$ & Sp & UK \\
\hline \multicolumn{14}{|c|}{$R R_{a b}-$ In work to Unemployment Transition } \\
\hline$<40$ & 3 & 3 & 2 & 0 & 6 & 25 & 12 & 24 & 2 & 2 & 13 & 12 & 15 \\
\hline $40-80$ & 35 & 40 & 40 & 15 & 56 & 51 & 44 & 60 & 26 & 32 & 65 & 32 & 59 \\
\hline $80+$ & 61 & 56 & 58 & 84 & 39 & 25 & 44 & 16 & 73 & 65 & 22 & 56 & 25 \\
\hline Total & 100 & 100 & 100 & 100 & 100 & 100 & 100 & 100 & 100 & 100 & 100 & 100 & 100 \\
\hline Average Replacement Rate & 81 & 79 & 81 & 87 & 71 & 58 & 72 & 57 & 84 & 83 & 68 & 74 & 63 \\
\hline \multicolumn{14}{|c|}{$R R_{b a}-$ Unemployment to In Work Transition } \\
\hline$<40$ & 2 & 7 & 7 & 5 & 12 & 14 & 5 & 16 & 9 & 12 & 7 & 12 & 13 \\
\hline $40-80$ & 38 & 56 & 42 & 35 & 50 & 52 & 54 & 60 & 31 & 47 & 45 & 41 & 63 \\
\hline $80+$ & 61 & 38 & 51 & 59 & 39 & 34 & 40 & 24 & 60 & 41 & 48 & 47 & 24 \\
\hline Total & 100 & 100 & 100 & 100 & 100 & 100 & 100 & 100 & 100 & 100 & 100 & 100 & 100 \\
\hline Average Replacement Rate & 84 & 73 & 81 & 84 & 71 & 66 & 72 & 63 & 87 & 71 & 84 & 77 & 64 \\
\hline \multicolumn{14}{|c|}{$R R_{c a}$-Inactive to In Work Transition } \\
\hline$<40$ & 1 & 14 & 7 & 7 & 12 & 7 & 3 & 5 & 2 & 8 & 14 & 11 & 8 \\
\hline $40-80$ & 40 & 58 & 60 & 58 & 58 & 50 & 61 & 39 & 47 & 54 & 59 & 51 & 67 \\
\hline $80+$ & 58 & 28 & 33 & 35 & 30 & 43 & 36 & 56 & 51 & 38 & 27 & 39 & 25 \\
\hline Total & 100 & 100 & 100 & 100 & 100 & 100 & 100 & 100 & 100 & 100 & 100 & 100 & 100 \\
\hline Average Replacement Rate & 91 & 68 & 70 & 72 & 67 & 75 & 73 & 84 & 81 & 72 & 65 & 71 & 67 \\
\hline
\end{tabular}
Source: EUROMOD. 
Table 3(a) Out of Work Components of Replacement Income as Percentage of In-work Income ( $R R_{a b}$ - In work to Unemployment Transition): 1998

\begin{tabular}{|c|c|c|c|c|c|c|c|c|c|c|c|c|c|}
\hline$R R_{a b} \quad$ Decomposition & At & Be & Dk & Fr & Ge & Gr & Ir & It & $\mathbf{L u}$ & Nl & $\mathbf{P t}$ & Sp & $\mathbf{U K}$ \\
\hline$<40$ Marginal Benefit & 58 & 78 & 52 & 145 & 51 & 21 & 66 & 31 & 96 & 74 & 33 & 68 & 44 \\
\hline Benefits in work & 14 & 9 & 7 & 5 & 16 & 28 & 13 & 19 & 5 & 13 & 17 & 18 & 8 \\
\hline Marginal Tax & 343 & 306 & 421 & 278 & 148 & 206 & 115 & 176 & 202 & 358 & 149 & 167 & 117 \\
\hline In-Work Tax & -350 & -333 & -469 & -349 & -155 & -217 & -118 & -197 & -229 & -388 & -169 & -187 & -132 \\
\hline Other Household Income & 35 & 40 & 90 & 21 & 40 & 62 & 24 & 71 & 25 & 44 & 70 & 33 & 63 \\
\hline Average RR & 22 & 27 & 25 & 31 & 29 & 15 & 25 & 22 & 26 & 23 & 28 & 19 & 27 \\
\hline 40- 80 Marginal Benefit & 39 & 49 & 62 & 95 & 42 & 23 & 31 & 11 & 67 & 100 & 14 & 56 & 19 \\
\hline Benefits in work & 14 & 16 & 12 & 5 & 13 & 11 & 17 & 22 & 11 & 8 & 17 & 9 & 8 \\
\hline Marginal Tax & 50 & 54 & 66 & 38 & 66 & 25 & 30 & 30 & 29 & 30 & 36 & 21 & 27 \\
\hline In-Work Tax & -69 & -76 & -118 & -60 & -83 & -45 & -40 & -61 & -58 & -64 & -62 & -38 & -50 \\
\hline Other Household Income & 66 & 58 & 79 & 22 & 61 & 85 & 62 & 98 & 51 & 26 & 96 & 52 & 97 \\
\hline Average RR & 67 & 66 & 66 & 74 & 64 & 63 & 62 & 63 & 69 & 72 & 57 & 64 & 60 \\
\hline 80+ Marginal Benefit & 27 & 26 & 44 & 39 & 18 & 20 & 14 & 3 & 42 & 41 & 7 & 30 & 11 \\
\hline Benefits in work & 20 & 19 & 14 & 12 & 12 & 17 & 11 & 22 & 17 & 10 & 19 & 15 & 10 \\
\hline Marginal Tax & 13 & 13 & 14 & 15 & 20 & 9 & 6 & 8 & 4 & 8 & 7 & 4 & 4 \\
\hline In-Work Tax & -39 & -42 & -80 & -38 & -56 & -28 & -24 & -47 & -27 & -48 & -36 & -21 & -31 \\
\hline Other Household Income & 80 & 84 & 108 & 71 & 106 & 81 & 93 & 114 & 64 & 89 & 103 & 71 & 106 \\
\hline Average RR & 92 & 91 & 91 & 89 & 89 & 88 & 92 & 87 & 90 & 90 & 83 & 91 & 89 \\
\hline
\end{tabular}

Source: EUROMOD 
Table 3(b) Out of Work Components of Replacement Income as Percentage of In-work Income ( $R R_{b a}$-Unemployment to In Work Transition): 1998

\begin{tabular}{crrrrrrrrrrrrr}
\hline$R R_{b a} \quad$ Decomposition & At & Be & Dk & Fr & Ge & Gr & Ir & It & Lu & NI & Pt & Sp & UK \\
\hline <40 Marginal Benefit & 20 & 62 & 62 & 66 & 66 & 10 & 81 & -4 & 56 & 56 & 13 & 40 & 60 \\
Benefits in work & 0 & 18 & 22 & 13 & 15 & 27 & 18 & 56 & 8 & 13 & 29 & 30 & 8 \\
Marginal Tax & 149 & 235 & 274 & 159 & 239 & 113 & 124 & 141 & 85 & 272 & 134 & 101 & 120 \\
In-Work Tax & -179 & -252 & -309 & -171 & -245 & -125 & -124 & -160 & -100 & -301 & -143 & -108 & -131 \\
Other Household Income & 110 & 36 & 50 & 33 & 25 & 75 & 1 & 66 & 52 & 60 & 68 & 37 & 43 \\
Average RR & 33 & 31 & 29 & 28 & 30 & 22 & 28 & 24 & 36 & 25 & 25 & 27 & 29 \\
& & & & & & & & & & & & & \\
40- 80 Marginal Benefit & 12 & 32 & 40 & 37 & 38 & 1 & 36 & 4 & 39 & 24 & 12 & 18 & 28 \\
Benefits in work & 19 & 20 & 36 & 17 & 19 & 19 & 33 & 33 & 33 & 12 & 18 & 28 & 15 \\
Marginal Tax & 35 & 57 & 60 & 37 & 67 & 14 & 21 & 23 & 19 & 46 & 23 & 17 & 29 \\
In-Work Tax & -59 & -79 & -111 & -55 & -86 & -31 & -25 & -53 & -31 & -83 & -38 & -31 & -47 \\
Other Household Income & 93 & 70 & 75 & 63 & 62 & 97 & 35 & 93 & 41 & 101 & 86 & 68 & 76 \\
Average RR & 67 & 61 & 65 & 62 & 63 & 65 & 64 & 63 & 66 & 62 & 64 & 62 & 62 \\
& & & & & & & & & & & & \\
80+ Marginal Benefit & 12 & 36 & 40 & 31 & 34 & 0 & 17 & 8 & 39 & 30 & 52 & 19 & 21 \\
Benefits in work & 16 & 20 & 26 & 21 & 14 & 13 & 28 & 25 & 21 & 15 & 9 & 21 & 15 \\
Marginal Tax & 8 & 8 & 6 & 8 & 24 & 3 & 5 & 4 & 0 & 5 & 4 & 2 & 8 \\
In-Work Tax & -38 & -36 & -70 & -29 & -50 & -24 & -17 & -41 & -16 & -48 & -19 & -18 & -33 \\
Other Household Income & 102 & 72 & 97 & 69 & 78 & 107 & 66 & 104 & 56 & 97 & 54 & 76 & 88 \\
Average RR & 93 & 96 & 97 & 98 & 93 & 88 & 89 & 91 & 99 & 92 & 115 & 96 & 87 \\
\hline Sour & & & & & & & & & & & &
\end{tabular}

Source: EUROMOD 
Table 3(c) Out of Work Components of Replacement Income as Percentage of In-work Income ( $R R_{c a}$-Inactive to In Work Transition): 1998

\begin{tabular}{crrrrrrrrrrrrrr}
\hline$R R_{c a} \quad$ Decomposition & At & Be & Dk & Fr & Ge & Gr & Ir & It & Lu & NI & Pt & Sp & UK \\
\hline <40 Marginal Benefit & 11 & 32 & 9 & 17 & 61 & 11 & 61 & 15 & 17 & 23 & 20 & 10 & 48 \\
Benefits in work & 29 & 30 & 62 & 19 & 19 & 34 & 18 & 34 & 28 & 25 & 23 & 30 & 13 \\
Marginal Tax & 116 & 240 & 267 & 107 & 226 & 96 & 80 & 128 & 123 & 250 & 115 & 118 & 115 \\
In-Work Tax & -135 & -251 & -303 & -130 & -231 & -113 & -81 & -166 & -133 & -281 & -137 & -130 & -128 \\
Other Household Income & 78 & 49 & 66 & 88 & 25 & 71 & 22 & 88 & 65 & 84 & 79 & 72 & 51 \\
Average RR & 33 & 29 & 25 & 31 & 28 & 25 & 31 & 25 & 32 & 28 & 26 & 24 & 29 \\
& & & & & & & & & & & & \\
40- 80 Marginal Benefit & 6 & 15 & 20 & 6 & 14 & 3 & 13 & 14 & 6 & 12 & 6 & 4 & 21 \\
Benefits in work & 23 & 29 & 46 & 20 & 20 & 16 & 23 & 25 & 23 & 17 & 18 & 21 & 15 \\
Marginal Tax & 22 & 51 & 58 & 28 & 53 & 13 & 17 & 22 & 23 & 46 & 27 & 17 & 25 \\
In-Work Tax & -57 & -77 & -100 & -57 & -84 & -32 & -28 & -51 & -41 & -84 & -57 & -33 & -46 \\
Other Household Income & 106 & 82 & 78 & 103 & 97 & 100 & 75 & 90 & 89 & 110 & 106 & 92 & 85 \\
Average RR & 67 & 63 & 66 & 64 & 64 & 66 & 67 & 67 & 67 & 62 & 56 & 63 & 63 \\
& & & & & & & & & & & & \\
80+ Marginal Benefit & 23 & 25 & 8 & 9 & 14 & 8 & 5 & 22 & 14 & 16 & 21 & 6 & 24 \\
Benefits in work & 27 & 22 & 40 & 17 & 16 & 11 & 11 & 22 & 19 & 14 & 11 & 15 & 19 \\
Marginal Tax & 2 & 11 & 16 & 9 & 18 & 3 & 7 & 3 & 5 & 7 & 3 & 4 & 9 \\
In-Work Tax & -38 & -53 & -79 & -40 & -54 & -29 & -28 & -38 & -30 & -54 & -34 & -26 & -31 \\
Other Household Income & 87 & 93 & 115 & 106 & 106 & 107 & 105 & 91 & 92 & 116 & 99 & 102 & 79 \\
Average RR & 98 & 93 & 88 & 90 & 88 & 91 & 87 & 98 & 90 & 90 & 93 & 91 & 88 \\
\hline
\end{tabular}

Source: EUROMOD 
Table 4 Characteristics that Influence Replacement Rates

\begin{tabular}{|c|c|c|c|c|c|c|c|c|c|c|c|c|}
\hline Country & At & & $\mathbf{B e}$ & & Dk & & $\mathbf{F r}$ & & Gr & & Ir & \\
\hline & Coef & $\mathrm{p}$ & Coef & $\mathrm{p}$ & Coef & $\mathrm{p}$ & Coef & $\mathrm{p}$ & Coef & $\mathrm{p}$ & Coef. & $\mathrm{p}$ \\
\hline In-Work Sample & -0.059 & 0.00 & 0.064 & 0.00 & -0.061 & 0.26 & 0.099 & 0.00 & 0.049 & 0.08 & & 0.03 \\
\hline Male & -0.052 & 0.00 & .053 & 0.00 & -0.121 & 0.01 & -0.036 & 0.00 & -0.079 & 0.02 & & .00 \\
\hline Aged $<=25$ & 0.030 & 0.02 & & 0.00 & & 0.52 & & 0.00 & & 0.54 & & .00 \\
\hline Unemp. Rate & 0.143 & 0.00 & & 0.10 & & 0.72 & & 0.94 & .203 & 0.01 & 0.229 & .00 \\
\hline Married & 0.014 & 0.17 & 020 & 0.15 & -0.068 & 0.15 & -0.013 & 0.00 & 0.098 & 0.00 & 0.018 & .03 \\
\hline Cohabiting & 0.005 & 0.77 & .078 & 0.00 & -0.039 & 0.42 & -0.002 & 0.66 & 0.004 & 0.96 & & .00 \\
\hline \# Ch. Aged 0-5 & -0.039 & 0.00 & .001 & 0.94 & -0.029 & 0.42 & 15 & 0.00 & & 0.04 & -0.037 & 0.00 \\
\hline \# Ch. Aged 6-10 & -0.032 & 0.00 & .009 & 0.40 & -0.035 & 0.38 & & 0.00 & & 0.01 & & 0.00 \\
\hline \#Ch. Aged 1 & -0.050 & 0.00 & .018 & 0.08 & -0.026 & 0.51 & -0.021 & 0.00 & -0.045 & 0.00 & -0.044 & 0.00 \\
\hline No. Pers. in $\mathrm{I}$ & & 0.00 & & 0.00 & & & & 0.00 & & 0.00 & & 0.00 \\
\hline Home Owner & 0.020 & 0.18 & & 0.15 & & 0.10 & & 0.62 & & 0.19 & 0.011 & 0.48 \\
\hline $\begin{array}{l}\text { Home Owner } \\
\text { (with Mortgage) }\end{array}$ & 0.008 & 0.60 & -0.024 & 0.08 & -0.154 & 0.00 & 0.010 & 0.00 & -0.017 & 0.68 & -0.016 & 0.28 \\
\hline Social Renter & 0.033 & 0.02 & 0.002 & 0.92 & -0.114 & 0.05 & 0.005 & 0.18 & 0.034 & 0.72 & -0.029 & 0.07 \\
\hline ig Costs & 0.000 & 0.06 & 00 & 0.19 & & 0.05 & & & & 0.60 & & 0.10 \\
\hline Const & 0.538 & 0.00 & 0.609 & 0.00 & 1.109 & 0.00 & 0.700 & 0.00 & 0.441 & 0.00 & 0.488 & 0.00 \\
\hline & & & 1430 & & 1738 & & 8022 & & & & 2458 & \\
\hline $\mathrm{R} 2$ & 0.219 & & 0.113 & & 0.024 & & 0.165 & & & & 0.391 & \\
\hline \multirow[t]{2}{*}{ Country } & It & & Lu & & Nl & & $\mathbf{P t}$ & & Sp & & $\mathbf{U K}$ & \\
\hline & Coef. & $\mathrm{p}$ & Coef. & $\mathrm{p}$ & Coef. & $\mathrm{p}$ & Coef. & $\mathrm{p}$ & Coef. & $\mathrm{p}$ & Coef. & $\mathrm{p}$ \\
\hline In-Work Sample & 0.032 & 0.00 & 0.139 & 0.00 & 0.080 & 0.00 & -0.075 & 0.00 & 66 & 0.00 & & 0.54 \\
\hline Male & -0.158 & 0.00 & -0.041 & 0.00 & -0.0 & 0.00 & -0. & 0.00 & & 0.00 & & 0.00 \\
\hline Aged $<=25$ & 0.072 & 0.00 & -0.028 & 0.00 & 0.040 & 0.00 & 0.0 & 0.02 & 0.0 & 0.00 & & 0.00 \\
\hline o. Rate & & 0.00 & & & & & & 0.20 & & 0.00 & & 0.18 \\
\hline Mar & -0.053 & 0.00 & -0.009 & 0.16 & & 0.36 & -0.0 & 0.10 & & 0.00 & & 0.01 \\
\hline Cohe & -0.020 & 0.56 & 0.026 & 0.00 & 0.030 & 0.02 & -0.009 & 0.73 & -0.011 & 0.66 & 0.044 & 0.00 \\
\hline & & 0.00 & & 0.17 & -0.029 & 0.00 & -0.0 & 0.22 & & 0.00 & & 0.00 \\
\hline \# Ch. Ag & -0.076 & 0.00 & -0.022 & 0.00 & -0.059 & 0.00 & 0.004 & 0.62 & -0.044 & 0.00 & -0.057 & 0.00 \\
\hline & & 0.00 & & & & 0.00 & & 0.01 & & 0.00 & & 0.00 \\
\hline & & 0.00 & 0.041 & 0.00 & & 0.00 & & 0.00 & & 0.00 & & 0.00 \\
\hline Home Owner & 0.032 & 0.16 & -0.029 & 0.00 & 0.014 & 0.54 & -0.004 & 0.68 & -0.041 & 0.00 & -0.035 & 0.08 \\
\hline $\begin{array}{l}\text { Home } \\
\text { (with }\end{array}$ & & & -0.032 & & 0.0 & 0.32 & -0.0 & 0.96 & & 0.24 & & 0.00 \\
\hline & & 0.00 & -0.020 & 0.67 & & 0.00 & & 0.99 & & 0.34 & 0.042 & 0.02 \\
\hline & 0.000 & 0.16 & 0.000 & 0.00 & 0.000 & 0.00 & 0.000 & 0.27 & 0.000 & 0.00 & 0.000 & 0.36 \\
\hline & 0.469 & 0.00 & 0.668 & 0.00 & 0.680 & 0.00 & 0.604 & 0.00 & 0.633 & 0.00 & 0.456 & 0.00 \\
\hline No. Observations & 6194 & & 2013 & & 2611 & & 2809 & & 4884 & & 5077 & \\
\hline $\mathrm{R} 2$ & 0.293 & & 0.240 & & 0.080 & & 0.171 & & 0.137 & & 0.104 & \\
\hline
\end{tabular}

Source: EUROMOD

Note: the "in-work sample" variable is a dummy whose value is one for people currently in work (individuals included in the $R R_{a b}$ sample) and zero otherwise (i.e., for those included in the $R R_{b a}$ sample). 
Table A.1. Data Sources

\begin{tabular}{|l|l|r|r|}
\hline Country & Base Dataset for EUROMOD & Date of collection & $\begin{array}{r}\text { Reference time } \\
\text { period for incomes }\end{array}$ \\
\hline Austria & $\begin{array}{l}\text { European Community Household Panel, } \\
\text { Austrian version }\end{array}$ & 1999 & annual 1998 \\
\hline Belgium & Panel Survey on Belgian Households (W6) & 1997 & annual 1996 \\
\hline Denmark & European Community Household Panel (W2) & 1995 & annual 1994 \\
\hline Finland & Income distribution survey & 1997 & annual 1996 \\
\hline France & Budget de Famille & $1994 / 5$ & annual 1993/4 \\
\hline Germany & German Socio-Economic Panel (W15) & 1998 & annual 1997 \\
\hline Greece & European Community Household Panel (W3) & 1996 & annual 1995 \\
\hline Ireland & Living in Ireland Survey (W1) & 1994 & month in 1994 \\
\hline Italy & Survey of Households Income and Wealth & 1996 & annual 1995 \\
\hline Luxembourg & PSELL-2 (W5) & 1999 & annual 1998 \\
\hline Netherlands & Sociaal-economisch panelonderzoek (W3) & 1996 & annual 1995 \\
\hline Portugal & European Community Household Panel (W3) & 1996 & annual 1995 \\
\hline Spain & European Community Household Panel (W3) & 1996 & annual 1995 \\
\hline UK & Family Expenditure Survey & $1995 / 6$ & month in 1995/6 \\
\hline
\end{tabular}

Table A.2. Sample Sizes (individuals)

\begin{tabular}{|c|c|c|c|c|c|c|c|c|c|c|c|c|c|}
\hline & At & $\mathbf{B e}$ & Dk & Fr & Ge & Gr & Ir & It & Lu & NI & $\mathbf{P t}$ & Sp & UK \\
\hline \multicolumn{14}{|c|}{$R R_{A}-$ In work to Unemployment Transition } \\
\hline$<40$ & 86 & 58 & 50 & 17 & 466 & 864 & 407 & 1440 & 42 & 76 & 259 & 577 & 932 \\
\hline $40-80$ & 950 & 754 & 800 & 1342 & 4636 & 1760 & 1518 & 3651 & 622 & 1201 & 1280 & 1539 & 3625 \\
\hline $80+$ & 1647 & 1052 & 1151 & 7399 & 3210 & 854 & 1495 & 967 & 1767 & 2420 & 445 & 2706 & 1544 \\
\hline Total & 2684 & 1863 & 2001 & 8759 & 8312 & 3479 & 3420 & 6058 & 2431 & 3697 & 1984 & 4822 & 6101 \\
\hline \multicolumn{14}{|c|}{$R R_{B}-$ Unemployment to In Work Transition } \\
\hline$<40$ & 5 & 24 & 38 & 70 & 151 & 104 & 51 & 263 & 5 & 113 & 7 & 173 & 76 \\
\hline $40-80$ & 108 & 204 & 234 & 474 & 645 & 395 & 517 & 992 & 18 & 442 & 44 & 580 & 366 \\
\hline $80+$ & 174 & 138 & 287 & 793 & 503 & 261 & 383 & 398 & 36 & 378 & 47 & 676 & 140 \\
\hline Total & 288 & 367 & 559 & 1337 & 1299 & 761 & 951 & 1653 & 59 & 933 & 98 & 1429 & 582 \\
\hline \multicolumn{14}{|c|}{$R R_{C}$-Inactive to In Work Transition } \\
\hline$<40$ & 13 & 75 & 16 & 258 & 191 & 174 & 63 & 245 & 16 & 56 & 134 & 369 & 173 \\
\hline $40-80$ & 354 & 317 & 139 & 2139 & 890 & 1331 & 1270 & 1826 & 445 & 374 & 572 & 1748 & 1413 \\
\hline $80+$ & 508 & 153 & 76 & 1294 & 461 & 1156 & 746 & 2629 & 488 & 263 & 256 & 1344 & 534 \\
\hline Total & 875 & 545 & 231 & 3692 & 1542 & 2661 & 2079 & 4700 & 948 & 693 & 962 & 3461 & 2120 \\
\hline
\end{tabular}

Source: EUROMOD. 
Table A.3. Earnings Model

Male

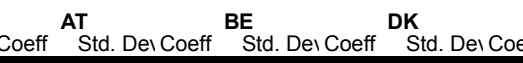

\section{FR GE GR}

Earnings Equation

Years In Education

Years of Experience ${ }^{\wedge}$

Region 1

Region 3

Region 4

Region 5

Region 6
Region 7

Region 8

Region 9

Region 10

Region 11

Region 12

Region 14

Region 14
Region 15

Region 16

Region 17

Region 19

Region 20

Region 21
Region 22

Region 22

Armed forces
Senior officials/managers

Professionals

Technici

Service and sales workers Skilled agricultural

Plant and machine operators

Part-time

Constant

Lambda

Marital Status
Cohabitting

Years In Education

Years of Experience

Regional Unemp. Rate

No. of Chldren (aged - 0 -5)

No. of Chldren (aged - 6-10)
No. of Chldren (aged - 11-17)

yrsed $m$

$t \mathrm{~m}$

Std. Der Coeff

Std. Del Coeff GR

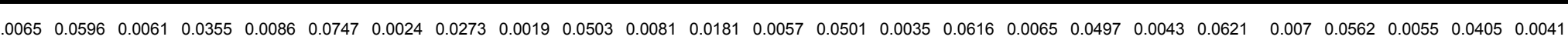

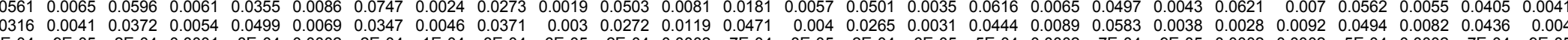

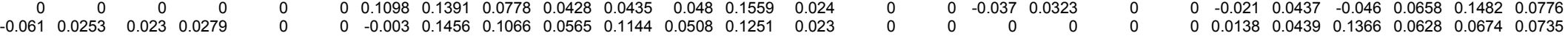

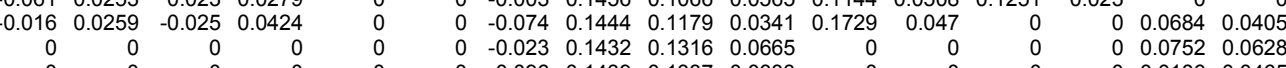
$\begin{array}{lllllllllll}0 & 0 & 0 & 0 & 0 & 0 & -0.096 & 0.1439 & 0.1337 & 0.0333\end{array}$ $\begin{array}{lllllllllll}0 & 0 & 0 & 0 & 0 & 0 & -0.102 & 0.146 & 0.1565 & 0.0375 \\ 0 & 0 & 0 & 0 & 0 & 0 & -0.104 & 0.1457 & 0.1061 & 0.0383\end{array}$ $\begin{array}{llllll}0 & 0 & -0.165 & 0.1413 & 0.1647 & 0.0356\end{array}$ $\begin{array}{rrrrrrrrrr}0 & 0 & 0 & 0 & 0 & 0 & -0.053 & 0.1423 & 0.1228 & 0.0357 \\ 0 & 0 & 0 & 0 & 0 & 0 & 0.0312 & 0.1429 & 0 & 0\end{array}$ $\begin{array}{llllllllll}0 & 0 & 0 & 0 & 0 & 0 & -0.138 & 0.147 & -0.137 & 0.0454 \\ 0 & 0 & 0 & 0 & 0 & 0 & -0.117 & 0.141 & -0.203 & 0.0369\end{array}$ $\begin{array}{llllllllll}0 & 0 & 0 & 0 & 0 & 0 & -0.214 & 0.1425 & -0.262 & 0.0353\end{array}$ $\begin{array}{llllllllll}0 & 0 & 0 & 0 & 0 & 0 & -0.108 & 0.1455 & -0.288 & 0.0361 \\ 0 & 0 & 0 & 0 & 0 & 0 & -0.159 & 0.1423 & -0.242 & 0.0356\end{array}$ $\begin{array}{llllllllll}0 & 0 & 0 & 0 & 0 & 0 & -0.084 & 0.1427 & -0.2 & 0.0343 \\ 0 & 0 & 0 & 0 & 0 & 0 & -162 & 0.1534 & 0 & 0\end{array}$

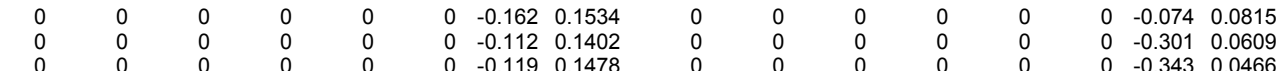

$\begin{array}{llllllllllllllll}0 & 0 & 0 & 0 & 0 & 0 & -0.119 & 0.1478 & 0 & 0 & 0 & 0 & 0 & 0 & -0.343 & 0.0466 \\ 0 & 0 & 0 & 0 & 0 & 0 & -0.174 & 0.1441 & 0 & 0 & 0 & 0 & 0 & 0 & -0.263 & 0.0549\end{array}$

$\begin{array}{llllllrr}0 & 0 & 0 & 0 & 0 & 0 & 0.0041 & 0.141 \\ 0 & 0 & 0 & 0 & 0 & 0 & 0 & 0\end{array}$

\begin{tabular}{l|l} 
reg19 m & \\
reg20 m & 0 \\
reg2 21 & 0 \\
reg $22 \mathrm{~m}$ & 0 \\
m & 0
\end{tabular}

$\begin{array}{rrr}0.4874 & 0.0492 \\ 0.4905 & 0.0644\end{array}$

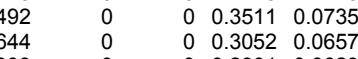

$\begin{array}{llllll}0.3559 & 0.0393 & 0 & 0 & 0.2901 & 0.0629 \\ 0.2361 & 0.0445 & 0 & 0 & 0.1891 & 0.0717\end{array}$

$\begin{array}{ll}-0.232 & 0.0637 \\ 0.1833 & 0.0354 \\ 0.1122 & 0.0429\end{array}$

$\begin{array}{lll}0 & 0.0578 & 0.072 \\ 0 & -0.018 & 0.1093\end{array}$ $\begin{array}{llll}0 & 0.0186 & 0.0465 \\ 0 & 0.0412 & 0.0533\end{array}$ $\begin{array}{lrrr}0 & -0.08 & 0.0511 \\ 0 & 0.0723 & 0.0429\end{array}$

$\begin{array}{llll}0 & -0.002 & 0.0453 \\ 0 & -0.109 & 0.0574\end{array}$

$\begin{array}{rrrr}0 & -0.109 & 0.0574 \\ 0 & -0.096 & 0.0525\end{array}$

$\begin{array}{lll}0 & -0.058 & 0.0478 \\ 0 & -0.125 & 0.0562\end{array}$

$\begin{array}{llll}0 & 0.125 & 0.0562 \\ 0 & 0.0146 & 0.0996 \\ 0 & -0.269 & 0.0434 \\ 0 & -0.234 & 0.0451\end{array}$

$\begin{array}{lll}0 & -0.343 & 0.0466 \\ 0 & -0.263 & 0.0549 \\ 0 & & 0\end{array}$

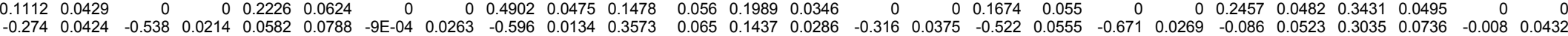

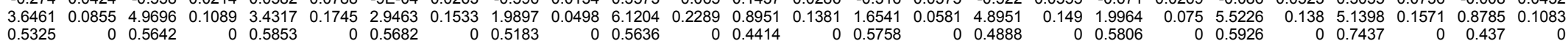
constant sd m

marr $p m$
partner $p m$

$\begin{array}{lllllllllllllllllllllllllll}0.4343 & 0.0846 & 0.7498 & 0.0468 & 0.8154 & 0.108 & 0.9122 & 0.0589 & 0.4771 & 0.0346 & 0.6678 & 0.0853 & 0.6493 & 0.0831 & 0.6153 & 0.063 & 0.5944 & 0.1263 & 0.8011 & 0.0686 & 0.6777 & 0.0771 & 0.9045 & 0.0675 & 0.8188 & 0.0652\end{array}$ yrsed $p \mathrm{~m}$ t $\mathrm{pm}$ REGUNEMP $p$ m

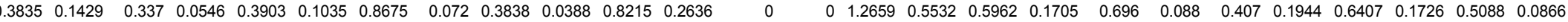

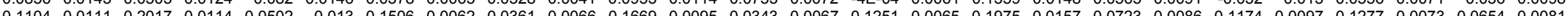

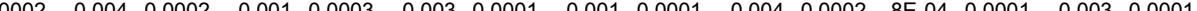

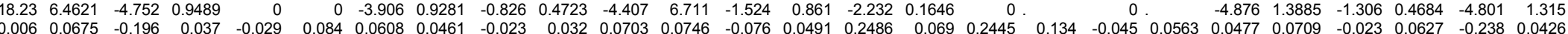

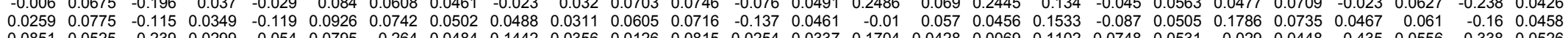
Constant

nch610 p m

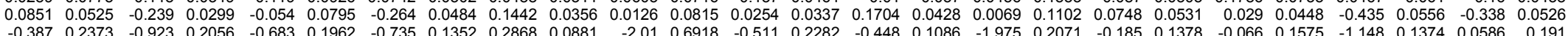

Note: for NL the occupational categories are 1: mentary; 2: lower; 3: intermediate; 4: higher; 5: scientific occupations 


\section{Marital Status
Cohabitting}

Years In Education

Years of Experience

Rears of Experience 22

No. of Chldren (aged $-0-5$ )

No. of Chldren (aged - 6-10)

Constant

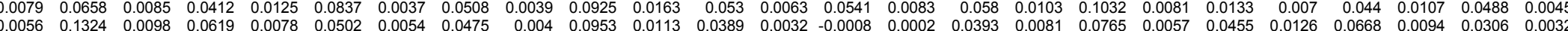

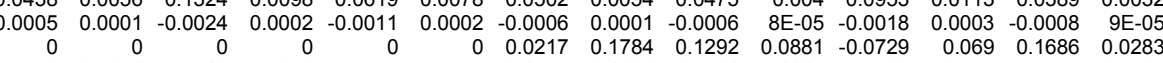
$\begin{array}{rrrr}0.049 & 0.0371 & -0.0713 & 0.0623\end{array}$ $\begin{array}{rr}-0.0086 & 0.0624 \\ 0 & 0 \\ 0 & 0\end{array}$

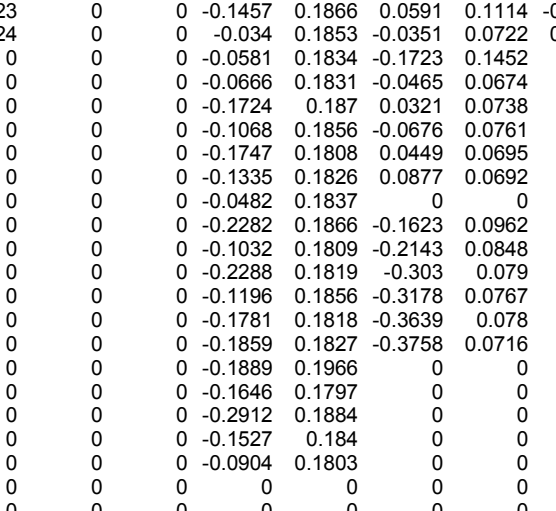

\begin{tabular}{|c|c|c|c|c|}
\hline 0.069 & 0.1686 & 0.0283 & & $0-0$ \\
\hline 0.074 & 0.044 & 0.0264 & & \\
\hline & & & 0.0507 & 0.0559 \\
\hline & 0 & & 0.086 & $\begin{array}{ll}6 & 0.0827\end{array}$ \\
\hline 0 & 0 & & -0.0594 & $\begin{array}{ll}4 & 0.0657 \\
2 & 0.0774\end{array}$ \\
\hline 0 & 0 & & 0.0912 & $\begin{array}{ll}2 & 0.0774 \\
3 & 0.0773\end{array}$ \\
\hline 0 & 0 & & 0.0423 & $\begin{array}{cc}3 & 0.0569 \\
3 & 0.056\end{array}$ \\
\hline 0 & 0 & & -0.0312 & $\begin{array}{ll}2 & 0.0629\end{array}$ \\
\hline 0 & 0 & & -0.2056 & $\begin{array}{ll}6 & 0.0813\end{array}$ \\
\hline 0 & 0 & & -0.1097 & $\begin{array}{ll}7 & 0.0685\end{array}$ \\
\hline 0 & 0 & & -0.2932 & $\begin{array}{ll}2 & 0.0708\end{array}$ \\
\hline 0 & 0 & & -0.071 & $\begin{array}{ll}3 & 0.0777\end{array}$ \\
\hline & 0 & & -0.099 & $\begin{array}{ll}9 & 0.1922\end{array}$ \\
\hline 0 & 0 & & -0.330 & $\begin{array}{ll}1 & 0.0736\end{array}$ \\
\hline & $\begin{array}{l}0 \\
0\end{array}$ & & -0.311 & $\begin{array}{ll}6 & 0.0738\end{array}$ \\
\hline 0 & 0 & & $\begin{array}{r}0.023 \\
-0.23\end{array}$ & $\begin{array}{ll}6 & 0.1496 \\
1 & 0.0972\end{array}$ \\
\hline 0 & 0 & & -0.219 & $\begin{array}{ll}4 & 0.082\end{array}$ \\
\hline & 0 & & -0.219 & $\begin{array}{ll}5 & 0.0879\end{array}$ \\
\hline & & & & \\
\hline & 0 & & & \\
\hline
\end{tabular}
$\begin{array}{llllllllll}0.0081 & 0.0765 & 0.0057 & 0.0455 & 0.0126 & 0.0668 & 0.0094 & 0.0306 & 0.0032\end{array}$

$\begin{array}{llllllllllllllllllllllllllllll}0.1359 & 0.0605 & 0.1121 & 0.0791 & 0.2967 & 0.0846 & 0.004 & 0.042 & -0.0237 & 0.0528 & -0.4454 & 0.0637 & -0.0347 & 0.0677 & -0.3881 & 0.0501 & -0.398 & 0.0794 & 0.0876 & 0.0741 & 0.1628 & 0.0548 & -0.1565 & 0.0536 & 0.3287 & 0.0489\end{array}$

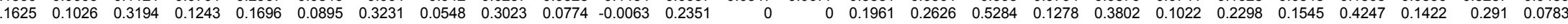
$\begin{array}{lllllllllllllllllllllllllll}0.0617 & 0.0118 & 0.065 & 0.0133 & 0.117 & 0.0125 & 0.082 & 0.0049 & 0.0507 & 0.0051 & 0.1605 & 0.0096 & 0.0807 & 0.0078 & 0.085 & 0.0054 & 0.052 & 0.0112 & 0.0556 & 0.009 & 0.0243 & 0.009 & 0.1269 & 0.0064 & 0.0737 & 0.009\end{array}$

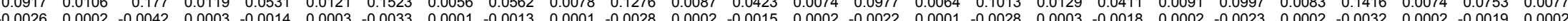

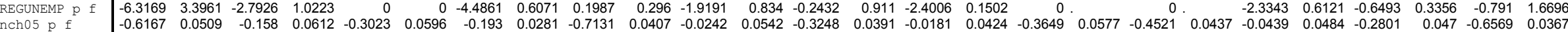
$n$
nch 610

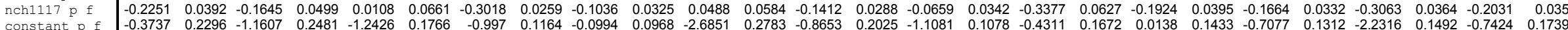

Note: for NL the occupational categories are 1: mentary; 2: lower; 3: intermediate; 4: higher; 5: scientific occupations 


\section{CESifo Working Paper Series}

(for full list see www.cesifo.de)

1027 José A. Herce, Namkee Ahn, Ricard Génova, and Joaquín Pereira, Bio-Demographic and Health Aspects of Ageing in the EU, September 2003

1028 John Komlos and Marieluise Baur, From the Tallest to (One of) the Fattest: The Enigmatic Fate of the American Population in the $20^{\text {th }}$ Century, September 2003

1029 Stefan Napel and Mika Widgrén, Bargaining and Distribution of Power in the EU's Conciliation Committee, September 2003

1030 Kai Li and Dale J. Poirier, Relationship Between Maternal Behavior During Pregnancy, Birth Outcome, and Early Childhood Development: An Exploratory Study, September 2003

1031 Ivar Ekeland, James J. Heckman, and Lars Nesheim, Identifcation and Estimation of Hedonic Models, September 2003

1032 Kjetil Bjorvatn and Alexander W. Cappelen, Decentralization and the Fate of Minorities, September 2003

1033 Lars-Erik Borge and Jørn Rattsø, The Relationships Between Costs and User Charges: The Case of a Norwegian Utility Service, September 2003

1034 Maureen Were and Nancy N. Nafula, An Assessment of the Impact of HIV/AIDS on Economic Growth: The Case of Kenya, September 2003

1035 A. Lans Bovenberg, Tax Policy and Labor Market Performance, September 2003

1036 Peter Birch Sørensen, Neutral Taxation of Shareholder Income: A Norwegian Tax Reform Proposal, September 2003

1037 Roberta Dessi and Sheilagh Ogilvie, Social Capital and Collusion: The Case of Merchant Guilds, September 2003

1038 Alessandra Casarico and Carlo Devillanova, Capital-skill Complementarity and the Redistributive Effects of Social Security Reform, September 2003

1039 Assaf Razin and Efraim Sadka, Privatizing Social Security Under Balanced-Budget Constraints: A Political-Economy Approach, September 2003

1040 Michele Moretto, Paolo M. Panteghini, and Carlo Scarpa, Investment Size and Firm's Value under Profit Sharing Regulation, September 2003

1041 A. Lans Bovenberg and Peter Birch Sørensen, Improving the Equity-Efficiency Tradeoff: Mandatory Savings Accounts for Social Insurance, September 2003 
1042 Bas van Aarle, Harry Garretsen, and Florence Huart, Transatlantic Monetary and Fiscal Policy Interaction, September 2003

1043 Jerome L. Stein, Stochastic Optimal Control Modeling of Debt Crises, September 2003

1044 Thomas Stratmann, Tainted Money? Contribution Limits and the Effectiveness of Campaign Spending, September 2003

1045 Marianna Grimaldi and Paul De Grauwe, Bubbling and Crashing Exchange Rates, September 2003

1046 Assar Lindbeck and Dennis J. Snower, The Firm as a Pool of Factor Complementarities, September 2003

1047 Volker Grossmann, Firm Size and Diversification: Asymmetric Multiproduct Firms under Cournot Competition, September 2003

1048 Dan Anderberg, Insiders, Outsiders, and the Underground Economy, October 2003

1049 Jose Apesteguia, Steffen Huck and Jörg Oechssler, Imitation - Theory and Experimental Evidence, October 2003

1050 G. Abío, G. Mahieu and C. Patxot, On the Optimality of PAYG Pension Systems in an Endogenous Fertility Setting, October 2003

1051 Carlos Fonseca Marinheiro, Output Smoothing in EMU and OECD: Can We Forego Government Contribution? A Risk Sharing Approach, October 2003

1052 Olivier Bargain and Nicolas Moreau, Is the Collective Model of Labor Supply Useful for Tax Policy Analysis? A Simulation Exercise, October 2003

1053 Michael Artis, Is there a European Business Cycle?, October 2003

1054 Martin R. West and Ludger Wößmann, Which School Systems Sort Weaker Students into Smaller Classes? International Evidence, October 2003

1055 Annette Alstadsaeter, Income Tax, Consumption Value of Education, and the Choice of Educational Type, October 2003

1056 Ansgar Belke and Ralph Setzer, Exchange Rate Volatility and Employment Growth: Empirical Evidence from the CEE Economies, October 2003

1057 Carsten Hefeker, Structural Reforms and the Enlargement of Monetary Union, October 2003

1058 Henning Bohn and Charles Stuart, Voting and Nonlinear Taxes in a Stylized Representative Democracy, October 2003

1059 Philippe Choné, David le Blanc and Isabelle Robert-Bobée, Female Labor Supply and Child Care in France, October 2003 
1060 V. Anton Muscatelli, Patrizio Tirelli and Carmine Trecroci, Fiscal and Monetary Policy Interactions: Empirical Evidence and Optimal Policy Using a Structural New Keynesian Model, October 2003

1061 Helmuth Cremer and Pierre Pestieau, Wealth Transfer Taxation: A Survey, October 2003

1062 Henning Bohn, Will Social Security and Medicare Remain Viable as the U.S. Population is Aging? An Update, October 2003

1063 James M. Malcomson, Health Service Gatekeepers, October 2003

1064 Jakob von Weizsäcker, The Hayek Pension: An efficient minimum pension to complement the welfare state, October 2003

1065 Joerg Baten, Creating Firms for a New Century: Determinants of Firm Creation around 1900 , October 2003

1066 Christian Keuschnigg, Public Policy and Venture Capital Backed Innovation, October 2003

1067 Thomas von Ungern-Sternberg, State Intervention on the Market for Natural Damage Insurance in Europe, October 2003

1068 Mark V. Pauly, Time, Risk, Precommitment, and Adverse Selection in Competitive Insurance Markets, October 2003

1069 Wolfgang Ochel, Decentralising Wage Bargaining in Germany - A Way to Increase Employment?, November 2003

1070 Jay Pil Choi, Patent Pools and Cross-Licensing in the Shadow of Patent Litigation, November 2003

1071 Martin Peitz and Patrick Waelbroeck, Piracy of Digital Products: A Critical Review of the Economics Literature, November 2003

1072 George Economides, Jim Malley, Apostolis Philippopoulos, and Ulrich Woitek, Electoral Uncertainty, Fiscal Policies \& Growth: Theory and Evidence from Germany, the UK and the US, November 2003

1073 Robert S. Chirinko and Julie Ann Elston, Finance, Control, and Profitability: The Influence of German Banks, November 2003

1074 Wolfgang Eggert and Martin Kolmar, The Taxation of Financial Capital under Asymmetric Information and the Tax-Competition Paradox, November 2003

1075 Amihai Glazer, Vesa Kanniainen, and Panu Poutvaara, Income Taxes, Property Values, and Migration, November 2003

1076 Jonas Agell, Why are Small Firms Different? Managers' Views, November 2003 
1077 Rafael Lalive, Social Interactions in Unemployment, November 2003

1078 Jean Pisani-Ferry, The Surprising French Employment Performance: What Lessons?, November 2003

1079 Josef Falkinger, Attention, Economies, November 2003

1080 Andreas Haufler and Michael Pflüger, Market Structure and the Taxation of International Trade, November 2003

1081 Jonas Agell and Helge Bennmarker, Endogenous Wage Rigidity, November 2003

1082 Fwu-Ranq Chang, On the Elasticities of Harvesting Rules, November 2003

1083 Lars P. Feld and Gebhard Kirchgässner, The Role of Direct Democracy in the European Union, November 2003

1084 Helge Berger, Jakob de Haan and Robert Inklaar, Restructuring the ECB, November 2003

1085 Lorenzo Forni and Raffaela Giordano, Employment in the Public Sector, November 2003

1086 Ann-Sofie Kolm and Birthe Larsen, Wages, Unemployment, and the Underground Economy, November 2003

1087 Lars P. Feld, Gebhard Kirchgässner, and Christoph A. Schaltegger, Decentralized Taxation and the Size of Government: Evidence from Swiss State and Local Governments, November 2003

1088 Arno Riedl and Frans van Winden, Input Versus Output Taxation in an Experimental International Economy, November 2003

1089 Nikolas Müller-Plantenberg, Japan’s Imbalance of Payments, November 2003

1090 Jan K. Brueckner, Transport Subsidies, System Choice, and Urban Sprawl, November 2003

1091 Herwig Immervoll and Cathal O’Donoghue, Employment Transitions in 13 European Countries. Levels, Distributions and Determining Factors of Net Replacement Rates, November 2003 